\title{
Article \\ Influence of the COVID-19 Pandemic on Tourism in European Countries: Cluster Analysis Findings
}

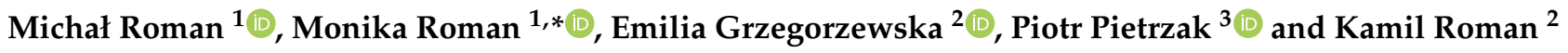 \\ 1 Institute of Economics and Finance, Warsaw University of Life Sciences, ul. Nowoursynowska 166, \\ 02-787 Warsaw, Poland; michal_roman@sggw.edu.pl \\ 2 Institute of Wood Sciences and Furniture, Warsaw University of Life Sciences, ul. Nowoursynowska 159, \\ 02-787 Warsaw, Poland; emilia_grzegorzewska@sggw.edu.pl (E.G.); kamil_roman@sggw.pl (K.R.) \\ 3 Management Institute, Warsaw University of Life Sciences, ul. Nowoursynowska 159, 02-776 Warsaw, Poland; \\ piotr_pietrzak1@sggw.edu.pl \\ * Correspondence: monika_roman@sggw.edu.pl
}

\section{check for}

updates

Citation: Roman, M.; Roman, M.; Grzegorzewska, E.; Pietrzak, P.; Roman, K. Influence of the COVID-19 Pandemic on Tourism in European Countries: Cluster Analysis Findings. Sustainability 2022, 14, 1602. https:// doi.org/10.3390/su14031602

Academic Editors: Juan Ignacio Pulido-Fernández, Isabel Carrillo-Hidalgo, José Luis Durán-Román and Fabio Carlucci

Received: 18 December 2021

Accepted: 26 January 2022

Published: 29 January 2022

Publisher's Note: MDPI stays neutral with regard to jurisdictional claims in published maps and institutional affiliations.

Copyright: (c) 2022 by the authors. Licensee MDPI, Basel, Switzerland. This article is an open access article distributed under the terms and conditions of the Creative Commons Attribution (CC BY) license (https:// creativecommons.org/licenses/by/ $4.0 /)$.

\begin{abstract}
This article aims to give an overview of tourism at the time of the global crisis caused by the COVID-19 pandemic. In order to assess the influence of the COVID-19 pandemic on European countries, the Systemic Literature Review (SLR) as well as Our World in Data (2021) and EUROSTAT (2021) secondary data were used. In order to group countries with respect to changes taking place in tourism, Ward's cluster analysis was applied. After verifying the available data, 31 European countries were eventually selected for the analysis. The application of Ward's method led to four groups of countries being created that are most similar in terms of changes in the tourism sector between 2019 and 2020. The first cluster comprised eight countries with the highest average rate of restrictiveness. On the other hand, this group recorded the lowest rate of changes concerning arrivals by air transport, which was on average $70.32 \%$. The second group comprised 13 countries. In this cluster, the average change in the number of overnight stays and arrivals at tourist resorts was the lowest in comparison with other clusters. The third cluster comprised four countries where the change in arrivals by air transport was the highest, with an average decrease of $81.76 \%$. The fourth group comprised six countries. The average change in the occupancy of hotel rooms and similar overnight accommodation facilities, as well as arrivals at tourist resorts, was the highest in comparison with other clusters. In addition, the countries were characterized by a relatively high decrease in the number of arrivals by air transport, but a relatively low average rate of restrictiveness.
\end{abstract}

Keywords: tourism; global challenges; crisis; COVID-19 pandemic; transport; Systematic Literature Review; cluster analysis; Ward's method

\section{Introduction}

Traveling and tourism constitute the largest service industry in the world and are constantly developing [1]. The industry stimulates the growth of the Gross Domestic Product (GDP) in host countries and considerably contributes to governments' tax revenues [2]. Before the pandemic, the travel and tourism sector accounted for $10.6 \%$ of all jobs (334 million) and 10.4\% of global GDP (USD 9.2 trillion). However, as a result of the COVID-19 crisis and the significant reduction in the mobility of tourists, in 2020 this sector generated USD 4.7 trillion, thus reducing its share in GDP to $5.5 \%$ [3].

Europe is the most popular tourist destination in the world, although it is not the fastest growing region in the world. Its market share in international tourist arrivals, and income from them, is falling [4,5]. In 2018, Europe was first in the world in terms of international arrivals: 713 million, which was over half of the global volume and a year-on-year rise of $6 \%$ in 2018 [6].

Tourism contributes, to a higher or lower degree, to the economic development of every country. Tourist traffic depends, among other things, on geographical location, 
natural attractions, and the political situation in a particular region. Tourism undoubtedly results in the inflow of capital, creates new workplaces, and is an impulse to develop other industries and sectors of a national economy (e.g., agriculture, gastronomy, and the construction industry). This results in growth to a local society's income and the economic mobilization of regions that are attractive in terms of tourism.

For some countries, including European states, the tourism industry constitutes one of the most important elements of the national economy, with tourist traffic resulting in improvements in the prosperity of residents and entire regions over recent decades. The negative consequences of the pandemic affected tourism in particular, leaving it facing great challenges now. The barriers to global travel, such as quarantine, obligatory COVID-19 tests, general recommendations to limit traveling, the limited adoption of global procedures concerning health and safety, the lack of coordination between particular countries' governments and public and private sectors, and a successive wave of infections, have all led to considerable economic losses [7]. Since February 1, 2021, 32\% of all destinations in the world have been totally closed to international tourism, and $34 \%$ have been partially closed. Only $2 \%$ of destinations had lifted all restrictions on traveling. At the beginning of 2021, COVID-19-related travel restrictions in international tourism were applied to 219 destinations in the world [8].

Notwithstanding an ever-improving understanding of the efficiency of public health protection measures, considerable progress in the testing technology, and the implementation of vaccination programs, the global epidemiological situation and the occurrence of new SARS-CoV-2 variants have resulted in maintaining and constantly adjusting restrictions on traveling [9]. Due to the fact that the crisis caused by the COVID-19 pandemic affected all tourist destinations, it is now obvious that the negative consequences for the tourism market are enormous in terms of scale and reach. As a result, the economic slump contributes to the decrease in the purchasing power of many households, forcibly limiting their share in tourist travel and considerably decreasing tourist traffic on a global scale. As Skare et al. [9] indicated, the negative consequences for tourism caused by the COVID-19 crisis will be significant, both in the short and long term, and it will take several years to rebuild this sector. Plzáková and Smeral [10] also emphasized that, as a result of strict restrictions and the related economic slowdown, the demand for tourism dropped dramatically in 2020.

The United Nations World Tourism Organization (WTO) estimated that the pandemic caused $80 \%$ of losses in tourist arrivals from abroad in 2020 [11]. On the other hand, Iacus and Natale [12] estimated that, according to the worst scenarios, as a result of the COVID-19 pandemic, restrictions on traveling might generate a loss of USD 323 billion and 30.3 million jobs globally. As indicated by the latest WTTC [3] research in connection with the COVID-19 pandemic, in 2020 the tourism sector suffered a loss of USD 4.5 trillion. Its value decreased by nearly $50 \%$ compared to the previous year. In addition, the number of jobs in tourism decreased by $18.5 \%$ or 62 million.

In addition, UNCTAD [13] forecasts show that the tourism sector will suffer a loss of between USD1.7 trillion and USD 2.4 trillion in 2021, compared to the 2019 level. Thus, the aim of this article is to assess and compare the influence of the COVID-19 pandemic on the tourism sector in European countries. To achieve this, the following research tasks were adopted: (1) to review literature on the influence of the COVID-19 pandemic on tourism and the crises in tourism; (2) to present changes in the tourism sector of European countries in the period 2019-2020; and (3) to cluster European countries with respect to changes that took place in the tourism sector as a result of the COVID-19 pandemic. This approach will not only allow the changes resulting from the pandemic in the individual countries to be assessed, but also allow the problem to be looked at on a broader scale, compared with the situation in non-European countries. The creation of clusters will help create groups of countries where the impact of the COVID-19 pandemic on the tourism sector was similar.

This article is comprised of six parts. The first part is an introduction, presenting the reasons for choosing this subject matter, the main objective, and the research tasks. 
The second part constitutes a review of the literature on the influence of the COVID-19 pandemic on tourism. The third part presents the material and research methods used. The fourth part presents the research findings. The fifth part is a discussion of other authors' findings. The article ends with conclusions and a presentation of limitations of the results obtained. This final part also contains suggestions concerning future research directions.

\section{Theoretical Background}

The tourism market is subject to constant change [14]. Global tourism has been exposed to many different crises in the past (the world-shaking terrorist attacks of 11 September 2001, the SARS syndrome in 2003, the global financial crisis of 2008/2009). SARS and the global financial crisis resulted in a decrease in international arrivals by air transport of $-0.4 \%$ and $4.0 \%$, respectively [15]. This might suggest that "tourism, as a system, is resilient to external shocks" [16,17]. However, there is abundant evidence that the consequences of and recovery from the COVID-19 pandemic will be unprecedented [15].

Tourism is perceived as a space-related phenomenon having an enormous influence on society and on various sectors of national economies at the time of the COVID-19 pandemic [18].

The sudden occurrence and scientific understanding of the COVID-19 pandemic, and the non-pharmaceutical interventions (NPI) to the pandemic, have changed over time, with tourism organizations encountering problems in understanding the scale of the situation [19]. Accordingly, forecasts were difficult at the time and all estimations of potential consequences for tourism should now be interpreted with extreme caution [15].

As a result of restrictions on traveling, global tourism slowed down considerably. For example, the seats offered by airlines were reduced by $50 \%$ in 2020 [20]. As the number of COVID-19 cases increased, bans on traveling grounded a growing number of carriers. The number of passengers probably fell even further, because many airlines adopted special rules for booking in order to maintain distance between passengers-for example, seat limitations introduced by Air New Zealand as a result of government regulations concerning social distance, meaning that the "full" seat occupancy in the airline was below $50 \%$ of its capacity [15].

The world has experienced many serious epidemics/pandemics over the last 40 years, but none of them have had such implications for the world economy as the COVID-19 pandemic. The SARS-CoV-2 virus is not as contagious as measles and not as deadly as Ebola, but people can transmit the virus for a few days before they develop symptoms. As a result, asymptomatic carriers transmit the virus before they realize that they should be isolating or undertaking other measures, such as keeping distance or wearing masks covering the mouth and nose to avoid spreading the virus when they talk, cough, or sneeze. Due to limited numbers of tests in many countries, as well as the unavailability of tests, it is believed that asymptomatic transmission of the virus is widespread [15].

Table 1 presents a list of publications on the influence of the COVID-19 pandemic on tourism.

Using the LSTM model, Polyzos, Samitas, and Spyridou presented forecasts concerning the COVID-19 pandemic on the arrivals of Chinese tourists in the USA and Australia. Research confirmed a considerable decrease in the numbers of Chinese tourists arriving in those countries. This finding may have clearly negative consequences for tourism in those countries, because a return to the former traveling trend will take at least a year. Due to the fact that China generates considerable income for the tourism industry all over the world, the situation may also concern other countries. The authors indicated that not only tourism will be hit by the pandemic, but also other related industries [21]. 
Table 1. List of publications on the influence of the COVID-19 pandemic on tourism.

\begin{tabular}{|c|c|c|}
\hline Authors & Title & Methods \\
\hline Polyzos, Samitas, Spyridou [21] & $\begin{array}{l}\text { Tourism demand and the COVID-19 } \\
\text { pandemic: an LSTM approach }\end{array}$ & $\begin{array}{l}\text { Period: 2003-2019 } \\
\text { Method: long short-term memory } \\
\text { (LSTM) }\end{array}$ \\
\hline Uğur and Akbiyık [22] & $\begin{array}{l}\text { Impacts of COVID-19 on global tourism } \\
\text { industry: a cross-regional comparison }\end{array}$ & $\begin{array}{l}\text { Period: } 2019-2020 \\
\text { Area: USA, Europe, Asia } \\
\text { Method: text mining } \\
\text { Period: } 1998-2020\end{array}$ \\
\hline Fotiadis, Polyzos, Huanc [23] & $\begin{array}{l}\text { The good, the bad and the ugly on } \\
\text { COVID-19 tourism recovery }\end{array}$ & $\begin{array}{c}\text { Area: world } \\
\text { Methods: long short-term memory } \\
\text { (LSTM), generalized additive model } \\
\text { (GAM) }\end{array}$ \\
\hline Kaushal, Srivastava [24] & $\begin{array}{l}\text { Hospitality and tourism industry amid } \\
\text { COVID-19 pandemic: perspectives on } \\
\text { challenges and learnings from India } \\
\text { tourism under the early phase of }\end{array}$ & $\begin{array}{c}\text { Period: } 2020 \\
\text { Area: India } \\
\text { Method: email interviews } \\
\text { Period: } 2020\end{array}$ \\
\hline Tran, Chen, Tseng, Liao [25] & $\begin{array}{l}\text { COVID-19 in four APEC economies: an } \\
\text { estimation with special focus on SARS } \\
\text { experiences }\end{array}$ & $\begin{array}{c}\text { Area: Taiwan, Hongkong, Thailand, New } \\
\text { Zealand } \\
\text { Method: regression }\end{array}$ \\
\hline Higgins-Desbiolles [26] & $\begin{array}{l}\text { Socializing tourism for social and } \\
\text { ecological justice after COVID-19 }\end{array}$ & $\begin{array}{l}\text { Period: 1999-2020 } \\
\text { Method: SLR } \\
\text { Period: } 2020\end{array}$ \\
\hline Qiu, Park, Li, Song [27] & $\begin{array}{l}\text { Social costs of tourism during the } \\
\text { COVID-19 pandemic }\end{array}$ & $\begin{array}{l}\text { Area: } 1627 \text { respondents of Hong Kong, } \\
\text { Guangzhou, and Wuhan } \\
\text { Methods: survey questionnaire, valuation } \\
\text { method }\end{array}$ \\
\hline Zheng, Goh, Weng [28] & $\begin{array}{l}\text { The effects of misleading media reports } \\
\text { about COVID-19 on Chinese tourists' } \\
\text { mental health: a perspective article }\end{array}$ & $\begin{array}{l}\text { Period: } 1995-2020 \\
\text { Method: SLR }\end{array}$ \\
\hline Brouder [29] & $\begin{array}{l}\text { Reset redux: possible evolutionary } \\
\text { pathways towards the transformation of } \\
\text { tourism in a COVID-19 world }\end{array}$ & $\begin{array}{l}\text { Period: } 2013-2020 \\
\text { Method: SLR }\end{array}$ \\
\hline $\begin{array}{c}\text { Farzanagen, Gholipour, Feizi, Nunkoo, } \\
\text { Andargoli [30] }\end{array}$ & $\begin{array}{l}\text { International tourism and outbreak of } \\
\text { coronavirus (COVID-19): a } \\
\text { cross - country Analysis }\end{array}$ & $\begin{array}{l}\text { Period: } 2020 \\
\text { Area: selected countries } \\
\text { Method: regression }\end{array}$ \\
\hline $\begin{array}{l}\text { Correa-Martinez, Kampmeier, Kumpers, } \\
\text { Schwierzeck, Hennies, Hafezi, Kuhn, } \\
\text { Pavenstadt, Ludwig, Mellmann [31] }\end{array}$ & $\begin{array}{c}\text { A pandemic in times of global tourism: } \\
\text { superspreading and exportation of } \\
\text { COVID-19 cases from a ski area in } \\
\text { Austria }\end{array}$ & $\begin{array}{l}\text { Period: } 2020 \\
\text { Area: Germany, Austria } \\
\text { Method: case study }\end{array}$ \\
\hline Yu, Li, Yu, He, Zhou [32] & $\begin{array}{c}\text { Communication related health crisis on } \\
\text { social media: a case of COVID-19 } \\
\text { outbreak }\end{array}$ & $\begin{array}{l}\text { Period: } 2020 \\
\text { Method: case study }\end{array}$ \\
\hline Niewiadomski [33] & $\begin{array}{c}\text { COVID-19: from temporary } \\
\text { deglobalization to a rediscovery of } \\
\text { tourism? }\end{array}$ & $\begin{array}{l}\text { Period: } 1987-2020 \\
\text { Method: SLR }\end{array}$ \\
\hline Carr [34] & $\begin{array}{l}\text { COVID-19, indigenous peoples and } \\
\text { tourism: a view from New Zealand }\end{array}$ & $\begin{array}{l}\text { Period: } 1979-2020 \\
\text { Method: SLR }\end{array}$ \\
\hline Chang, McAleer, Ramos [35] & $\begin{array}{l}\text { A charter for sustainable tourism after } \\
\text { COVID-19 } \\
\text { Lessons from COVID-19 can prepare }\end{array}$ & $\begin{array}{l}\text { Period: } 2020 \\
\text { Method: SLR }\end{array}$ \\
\hline Prideaux, Thompson, Pabel [36] & $\begin{array}{c}\text { global tourism for the economic } \\
\text { transformation needed to combat climate } \\
\text { change }\end{array}$ & $\begin{array}{l}\text { Period: } 2001-2020 \\
\text { Method: SLR }\end{array}$ \\
\hline Wen, Kozak, Yang, Liu [37] & $\begin{array}{l}\text { COVID-19: potential effects on Chinese } \\
\text { citizens' lifestyle and travel }\end{array}$ & $\begin{array}{l}\text { Period: } 2020 \\
\text { Method: SLR }\end{array}$ \\
\hline
\end{tabular}

Source: [21-37].

Uğur and Akbıyık carried out an analysis of tourist decisions and responses to the pandemic. In particular, their research focused on identifying the effects of the COVID-19 
pandemic on the global tourism sector in light of comments made by tourists from the United States, Europe, and Asia on the largest tourist platform-tripadvisor. The research showed that the sector is very vulnerable and easily affected by global crises. When COVID-19 was announced to be a pandemic, tourists immediately started canceling trips and discussing issues concerning travel guarantees. Travelers also need time to return to their former mobility, even when a crisis ends. The feelings of fear, anxiety, and uncertainty are present in society for a long time. This tendency additionally lengthens the revival time for the tourism industry [22].

On the other hand, Fotiadis, Polyzos, and Huan [23] presented various scenarios concerning international tourist demand in light of the COVID-19 pandemic. Based on data concerning the latest crises, they calculated the forecasted decrease in foreign tourist arrivals over the next 12 months. The research showed that the fall in tourist arrivals may be between $30.8 \%$ and $76.3 \%$ and will continue at least until June 2021. The COVID-19 pandemic will cause losses of about $50 \%$ in the subsequent year and the losses will continue to occur at least until the following summer, leaving the tourism industry back where it was 15 years ago. In those authors' opinion, a revitalization of tourism may be expected after the summer of 2021. Their conclusions conform to the research findings of Polyzos et al. [21], who indicated that a return to the trend of tourist arrivals on the level before the crisis may take as long as a year [23].

In Kaushal and Srivastava's opinion, the effects of the present pandemic will be clearer and will last longer than the effects of former crises, especially if the lack of a vaccine to develop herd immunity is taken into account. The authors indicated that sectors that are dependent on social contacts, such as tourism and the hotel business, will be especially vulnerable. In addition, the research drew attention to such aspects as the change in traveling and eating habits, lower spending, and the need to adapt [24].

Tran, Chen, Tsenga, and Liao examined how the experience of a severe course of COVID-19 influenced international tourist demand in Taiwan, Hong Kong, Thailand, and New Zealand. They indicated that the number of confirmed COVID-19 cases had a considerable negative effect on the demand for tourism, where a $\%$ increase in COVID-19 cases resulted in a fall in tourist arrivals by $0.075 \%$. The negative influence of COVID-19 on tourist arrivals in Thailand and New Zealand was much stronger than in Taiwan and Hong Kong. It also appeared that the number of national deaths related to COVID-19 had an even stronger influence on international tourism than the number of cases. In addition, it was claimed that traveling restrictions constitute a factor that has a strong influence on the number of tourist arrivals [25].

Higgins-Desbiolles believes that the COVID-19 pandemic of 2019-2020 will change the tourism industry and the context in which it operates. This global crisis, during which traveling, tourism, hotel business, and entertainment have been closed in many parts of the world, has created an opportunity to discover certain prospects from this historic moment of transformation [26].

Zheng, Goh, and Wen [28] presented the importance of media reports on COVID-19 on the mental health of Chinese tourists.

Brouder [29] presented the importance of COVID-19 as a once-in-a-lifetime chance in which an institutional pump is ready for transformation. The SARS-CoV-2 virus will have a visible effect on tourism demand and supply.

Niewiadomski [33] presented the importance of the COVID-19 pandemic for the development of tourism. In his opinion, the pandemic shows how important temporary deglobalization is to the rediscovery of tourism.

Carr [34] presented the consequences of the COVID-19 pandemic for tourism. In his opinion, these effects will be extensive and will have an intergenerational impact on indigenous and non-indigenous peoples.

Chang, McAleer, and Ramos [35] believe that the COVID-19 pandemic is highly contagious. The authors presented the long-term consequences for international communities. In their opinion, the COVID-19 pandemic has changed the world and tourism forever. 
Prideaux, Thompson, and Pabel [36] believe that the COVID-19 pandemic brought international travel to a halt in the first half of 2020. In their opinion, the tourism industry has suffered very significant economic losses.

Wen, Kozak, Yang, and Liu [37] focused on the importance of free and independent travel, luxury travel, and health and wellness tourism.

Correa-Martinez, Kampmeier, Kumpers, Schwierzeck, Hennies, Hafezi, Kuhn, Pavenstadt, Ludwig, and Mellmann [31] used case studies to present the influence of the COVID-19 pandemic on tourism. They presented the impact of the COVID-19 pandemic on skiing regions.

$\mathrm{Yu}, \mathrm{Li}, \mathrm{Yu}, \mathrm{He}$, and Zhou [32] made a contribution to suggestions and observations concerning future research into the field of tourism crises triggered by the epidemic.

Qiu, Park, Li, and Song carried out research into the potential tourism-related consequences of the COVID-19 pandemic with the use of the valuation method. In their opinion, residents are ready to cover the cost of reducing the risk of the pandemic [27].

The last group of authors, Farzanagen, Gholipour, Feizi, Nunkoo, and Andargoli, presented socio-economic determinants of the COVID-19 epidemic. Based on their estimations, as the level of inbound and outbound tourism rises by $1 \%$, the levels of confirmed COVID-19 cases and deaths increase by $1.2 \%$ and $1.4 \%$, respectively, taking into account other factors [30].

Summarizing this literature review, it is also worth mentioning three groups of authors [38-40] and their publications that were not included in Table 1. Nevertheless, their conclusions from their research showed the significant importance of the impact of the COVID-19 pandemic on tourism.

Felbermayr et al. [38] analyzed the geographic distribution of COVID-19 cases and deaths, taking into account data from 401 German districts. Based on these data, the authors confirmed that the geographical distance from the Austrian ski resort of Ischgl was an important prognostic factor for cases of COVID-19, but not for the mortality rates of this disease. Their research confirmed that if all German districts were located far from Ischgl (such as the district of Vorpommern-Rügen), German society would have recorded nearly half as many cases of COVID-19 infection. The authors concluded that the restrictive measures introduced in Germany, including lockdown, stopped the spread of the virus.

Nhamo et al. [39] presented a wide range of negative effects of the COVID-19 pandemic on the tourism sector, as well as a set of measures to reduce the socio-economic consequences of this situation, detailing various parts of the global tourism value chains. Among other things, they indicated the need to develop globally accepted certificates to improve both health and safety, especially for tourists and those working in tourism and tourism-related industries. In addition, their research indicated the need to build resilience that will enable the tourism industry to adapt to future market challenges similar to those it faces today.

Vasenska et al. [40] analyzed the impact of the COVID-19 pandemic on the tourism sector in Europe. The aim of their analysis was to compare the attitudes of Bulgarian tourists regarding travel, both before and after the COVID-19 threat. Research using a questionnaire was carried out among 121 respondents. Analysis confirmed that there were changes in travel before the first major crisis, during the period after isolation, and after the first major crisis. The authors emphasize that their study can be used in subsequent analyses aimed at assessing the attitudes of tourists in other crisis situations.

\section{Material and Methods}

One of the methods presented in this article is the Systematic Literature Review (SLR). Secondary data of Our World in Data [41] and EUROSTAT [42] were also used to evaluate the impact of the COVID-19 pandemic on tourism in European countries. After verifying the available data, 31 European countries were selected for analysis: Austria, Belgium, Bulgaria, Croatia, Cyprus, Czechia, Denmark, Estonia, Finland, France, Germany, Greece, Hungary, Iceland, Italy, Latvia, Lithuania, Luxembourg, Malta, the Netherlands, Norway, 
Poland, Portugal, Romania, Serbia, Slovakia, Slovenia, Spain, Sweden, Switzerland, and the United Kingdom.

This article compares data during the period of 2019-2020. Data from the full year 2020 were compared to data for the full year 2019. The variables that characterize the phenomenon under examination were selected based on substantive grounds. In our opinion, in order to analyze the impact of the COVID-19 pandemic, it is necessary to take into account not only data related to tourism, but also data characterizing the pandemic situation in particular countries. The introduced restrictions had an impact on the movement of people, and thus on the shaping of the situation in the tourism sector. This phenomenon covers many features and properties, known as diagnostic variables. Thus, the set of diagnostic variables is as follows:

X1: change of arrivals by air passenger transport [\%];

$\mathrm{X} 2$ : change in the occupancy rate at tourist accommodation establishments [\%];

X3: change of nights spent at tourist accommodation establishments by foreign visitors [\%];

X4: change of arrivals at tourist accommodation establishments [\%]; and

X5: average stringency index in 2020

Diagnostic variables may have different titers, different orders of magnitude, and different directions of influence on the assessed complex phenomenon; therefore, standardization is necessary. Table 2 presents selected statistical parameters of diagnostic variables and Table 3 shows the Pearson correlation coefficient matrix. It should be noted that the variables are characterized by rather weak correlation (not exceeding 0.6 ).

Table 2. Selected features of diagnostic variables adopted.

\begin{tabular}{|c|c|c|c|c|c|}
\hline Country & $X_{1}$ & $X_{2}$ & $X_{3}$ & $X_{4}$ & $X_{5}$ \\
\hline Austria & -74.28 & -22.93 & -44.04 & -47.55 & 57.95 \\
\hline Belgium & -72.89 & -35.37 & -69.13 & -59.15 & 54.18 \\
\hline Bulgaria & -67.86 & -18.50 & -62.64 & -41.67 & 42.68 \\
\hline Croatia & -81.13 & -31.78 & -57.95 & -64.21 & 45.82 \\
\hline Cyprus & -79.63 & -33.65 & -84.10 & -65.87 & 56.25 \\
\hline Czechia & -79.98 & -25.43 & -72.82 & -50.76 & 47.37 \\
\hline Denmark & -74.06 & -29.17 & -62.59 & -38.82 & 48.29 \\
\hline Estonia & -73.22 & -28.42 & -67.92 & -47.96 & 38.49 \\
\hline Finland & -75.06 & 2.49 & -67.53 & -40.92 & 41.11 \\
\hline France & -67.45 & -24.42 & -78.70 & -51.98 & 57.43 \\
\hline Germany & -74.20 & -27.94 & -64.45 & -48.63 & 54.81 \\
\hline Greece & -69.28 & -16.20 & -74.16 & -65.97 & 57.66 \\
\hline Hungary & -76.67 & -28.69 & -76.04 & -58.15 & 51.28 \\
\hline Iceland & -79.33 & -36.83 & -75.28 & -63.01 & 41.68 \\
\hline Italy & -72.52 & -22.40 & -70.21 & -59.30 & 68.41 \\
\hline Latvia & -74.32 & -23.45 & -60.94 & -47.11 & 45.02 \\
\hline Lithuania & -72.42 & -26.86 & -73.03 & -46.69 & 44.53 \\
\hline Luxembourg & -67.07 & -21.24 & -51.69 & -43.74 & 45.71 \\
\hline Malta & -76.28 & -49.35 & -74.59 & -65.11 & 48.40 \\
\hline Netherlands & -70.70 & -39.57 & -58.70 & -40.54 & 52.08 \\
\hline Norway & -62.26 & -20.48 & -68.99 & -40.36 & 44.14 \\
\hline Poland & -70.34 & -22.89 & -64.55 & -49.88 & 50.44 \\
\hline Portugal & -69.80 & -31.70 & -74.06 & -60.58 & 57.38 \\
\hline Romania & -69.43 & -16.75 & -81.09 & -49.90 & 52.84 \\
\hline Serbia & -70.84 & -15.94 & -68.45 & -50.50 & 52.25 \\
\hline Slovakia & -82.54 & -15.21 & -62.90 & -48.68 & 48.14 \\
\hline Slovenia & -83.37 & -22.55 & -70.58 & -47.78 & 52.91 \\
\hline Spain & -72.68 & -34.22 & -79.64 & -66.14 & 59.52 \\
\hline Sweden & -73.96 & -24.33 & -71.37 & -41.65 & 51.84 \\
\hline Switzerland & -71.81 & -21.94 & -54.03 & -35.42 & 44.73 \\
\hline UK & -71.48 & -48.38 & -77.14 & -71.72 & 60.18 \\
\hline
\end{tabular}


Table 2. Cont.

\begin{tabular}{cccccc}
\hline Country & $\mathbf{X}_{\mathbf{1}}$ & $\mathbf{X}_{\mathbf{2}}$ & $\mathbf{X}_{\mathbf{3}}$ & $\mathbf{X}_{\mathbf{4}}$ & $\mathbf{X}_{\mathbf{5}}$ \\
\hline & \multicolumn{2}{c}{ Descriptive statistics of variables } & & \\
Mean & -73.45 & -26.26 & -68.36 & -51.93 & 50.75 \\
Median & -72.89 & -24.42 & -69.13 & -49.88 & 51.28 \\
Minimum & -62.26 & 2.49 & -44.04 & -35.42 & 38.49 \\
Maximum & -83.37 & -49.35 & -84.1 & -71.72 & 68.41 \\
Standard deviation & 4.8 & 10.08 & 9.04 & 9.82 & 6.73 \\
Coefficient of variation & 6.54 & 38.37 & 13.22 & 18.92 & 13.26 \\
Skewedness & -0.21 & 0.02 & 0.69 & -0.33 & 0.38 \\
Kurtosis & 0.13 & 1.88 & 0.51 & -0.99 & 0.05 \\
\hline
\end{tabular}

Source: authors' own study.

Table 3. Correlation coefficient matrix.

\begin{tabular}{cccccc}
\hline Variables & $\mathbf{X}_{\mathbf{1}}$ & $\mathbf{X}_{\mathbf{2}}$ & $\mathbf{X}_{\mathbf{3}}$ & $\mathbf{X}_{\mathbf{4}}$ & $\mathbf{X}_{\mathbf{5}}$ \\
\hline $\mathrm{X}_{1}$ & 1.00 & & & & \\
$\mathrm{X}_{2}$ & 0.15 & 1.00 & & & \\
$\mathrm{X}_{3}$ & 0.05 & 0.24 & 1.00 & 1.00 & \\
$\mathrm{X}_{4}$ & 0.25 & 0.55 & 0.56 & 0.49 & 1.00 \\
$\mathrm{X}_{5}$ & -0.08 & 0.21 & 0.28 & &
\end{tabular}

Source: authors' own study.

A comparison of complex phenomena, such as determining the influence of the COVID-19 pandemic on the tourism sector in European countries, is possible, among other things, due to cluster analysis. The use of cluster analysis identified countries that have suffered similar losses in the tourism sector as a result of the COVID-19 pandemic. It was also important to take into account the government restrictions introduced, which had an impact on the functioning of economies, societies, and the tourism sectors of countries. Cluster analysis was applied to distinguish uniform sub-clusters of objects of the population under investigation, and in this sense it also came under the methods of Multivariate Comparative Analysis (MCA).

The potential spectrum of its application is very broad. Hans-Friedrich and Lawrence [43] and Rencher [44] reviewed literature devoted to this method to resolve problems in many areas of economic life. When applying cluster analysis, similarity or difference measures are based on the distance between units $\mathrm{d}(\mathrm{Oi}, \mathrm{Oj})$. The greater the distance between two objects (in this case countries), the more dissimilar they are. Thus, the objects in a cluster are those that are close to each other, but at the same time far from others comprising another cluster [45].

In this paper, a Euclidean distance is used:

$$
d(x, y)=\sqrt{\sum_{i=1}^{n}\left(x_{i}-y_{i}\right)^{2}}
$$

where $n=$ number of variables.

Variables are subject to standardization $\left(z_{i}\right)$ in accordance with the formula:

$$
z_{i}=\frac{x_{i}-\bar{x}}{s_{x}}
$$

where $\bar{x}=$ average and $s_{x}=$ standard deviation of a variable in a sample.

Based on the results, a square matrix of distance is created in the next step. Ward's hierarchical clustering is one of the most frequently used methods. Variance analysis is used in this method to estimate the distance between clusters. The method aims to minimize the 
sum of deviation squares inside clusters. The error sum of squares (ESS) is a measure of a cluster against the value of averages:

$$
E S S=\sum_{i=1}^{k}\left(x_{i}-\bar{x}\right)^{2}
$$

where $x_{i}=$ the value of a variable that is a criterion for segmentation for $i$ (this object), and $k=$ the number of objects in a cluster

To choose the number of clusters, the average silhouette index and Pseudo F were used.

\section{Results}

\subsection{Basic Information on the Tourism Sector in European Countries in 2019-2020}

One of the most popular means of transport in international tourist travel is by air [46]. In the years under investigation, passenger air transport arrivals in selected European countries decreased by $72 \%$ (Figure 1). The biggest decrease was reported in April (-99\%), May $(-98 \%)$, and June $(-95 \%)$. The biggest falls were recorded in Slovenia $(-83 \%)$, Slovakia $(83 \%)$, Croatia $(-81 \%)$, Czechia $(80 \%)$, and Cyprus $(80 \%)$. The smallest decreases in passenger air transport arrivals were recorded in Norway $(-62 \%)$, Luxembourg $(-67 \%)$, France $(-67 \%)$, Bulgaria $(-68 \%)$, and Greece $(-69 \%)$.

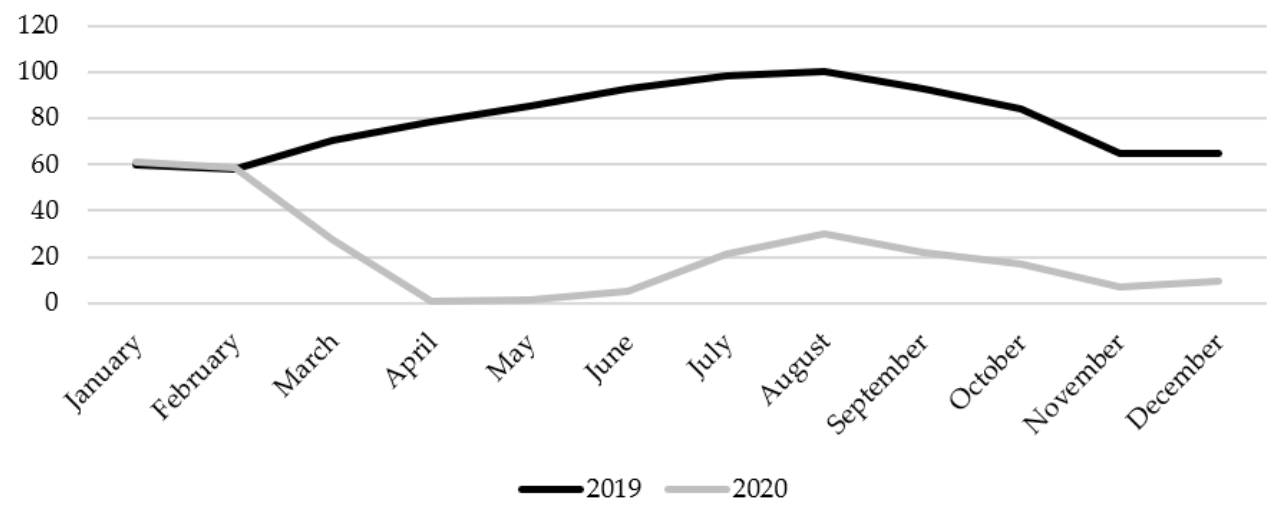

Figure 1. Arrivals by air passenger transport in selected European countries [in millions]. Source: authors' own preparation based on [42].

As a result of the considerably smaller number of arrivals by air transport, and by other means of transport, the total number of foreigners visiting particular countries also decreased (Figure 2). The most significant change took place in April (-97\%), May (-92\%), and December $(-86 \%)$. The countries that recorded far fewer foreign tourists in 2020 in comparison with 2019 are the United Kingdom (-72\%), Spain (-66\%), Greece (-66\%), Cyprus $(-66 \%)$, and Malta $(-65 \%)$. The smallest decreases in foreign tourists were recorded in Switzerland $(-35 \%)$, Denmark $(-39 \%)$, Norway $(-40 \%)$, the Netherlands $(-41 \%)$, and Finland $(-41 \%)$.

A considerable change was recorded in the number of nights spent at accommodation establishments (Figure 3). As in the case of air transport arrivals and the number of foreign visitors, the largest decreases in the number of nights spent at tourist accommodation establishments were recorded in April (-98\%), May (-98\%), and December $(-92 \%)$. The deepest falls in the number of overnight stays were recorded in Cyprus $(-84 \%)$, Romania $(-82 \%)$, Spain $(-80 \%)$, France $(-79 \%)$, and the United Kingdom $(-77 \%)$. On the other hand, the smallest changes occurred in Austria $(-44 \%)$, Luxembourg $(-52 \%)$, Switzerland $(-54 \%)$, Croatia $(-58 \%)$, and the Netherlands $(-59 \%)$. 


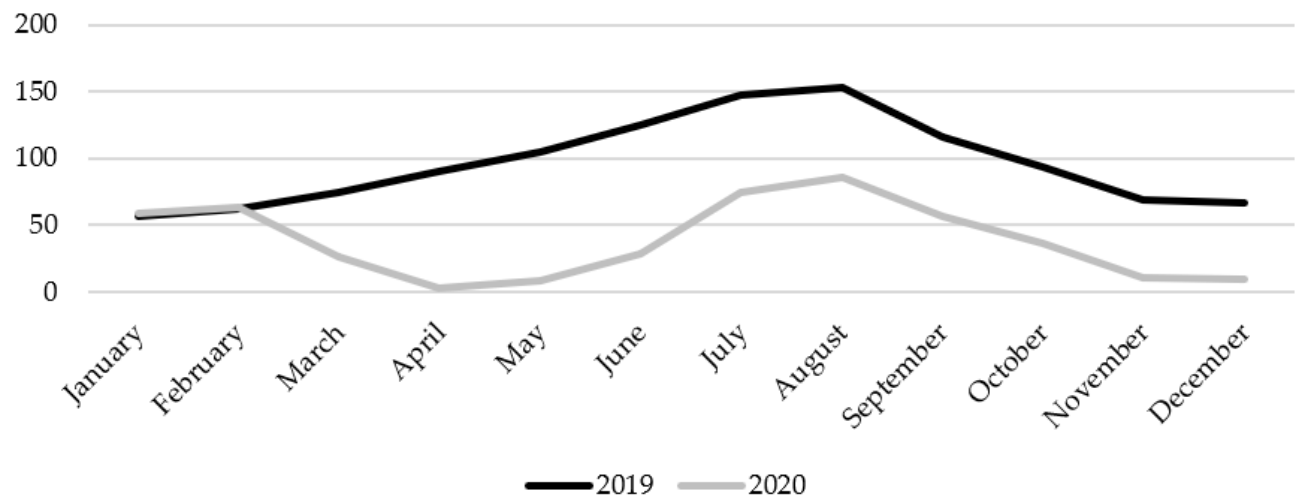

Figure 2. Arrivals at tourist accommodation establishments by foreign visitors in selected European countries [in millions]. Source: authors' own preparation based on [42].

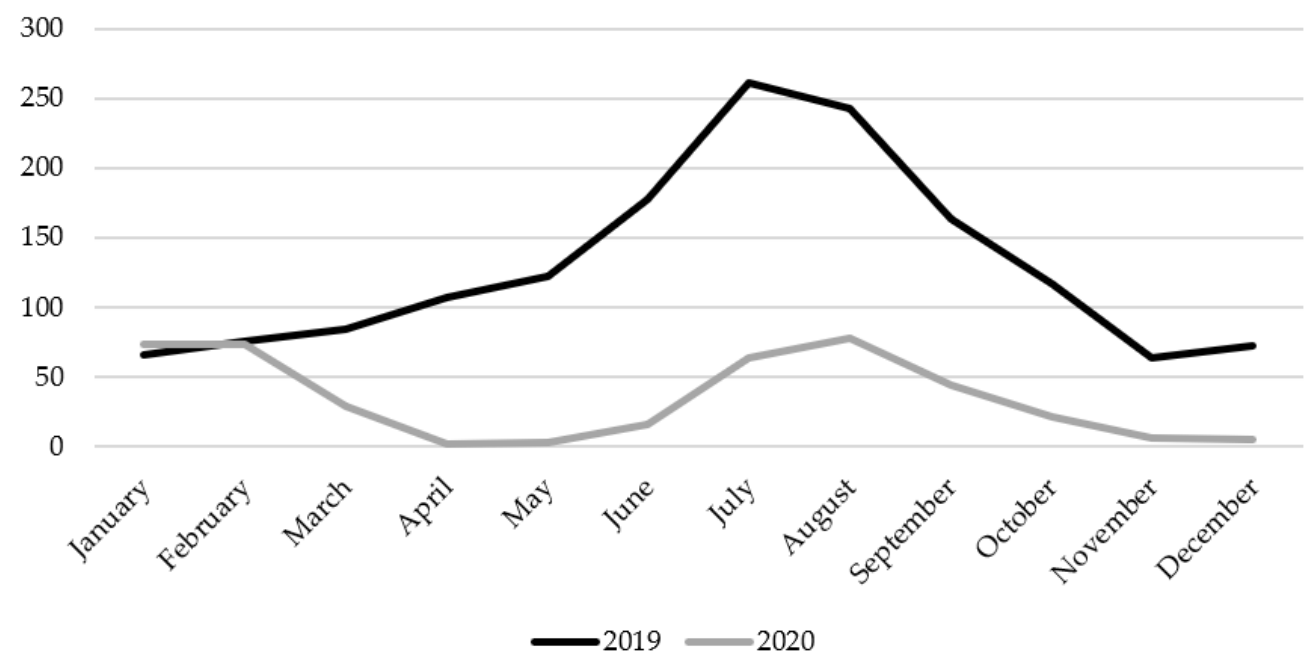

Figure 3. Nights spent at tourist accommodation establishments in selected European countries [in millions]. Source: authors' own preparation based on [42].

4.2. Cluster Analysis in the Field of the Impact of the COVID-19 Pandemic on the Tourism Sector of European Countries

The cluster analysis aimed to discover groupings of similar influence of the COVID-19 pandemic on tourism through a division into k clusters, so that the European countries from the same cluster are close to each other. The result of clustering is that a number of clusters comprised of particular countries are assigned to each of them. One of the first steps in this analysis was to determine the optimal number of clusters. Figure 4 presents the average silhouette index for a different number of clusters (from 1 to 6). Based on the results obtained, four clusters were determined (Figure 5).

The use of Ward's method made it possible to determine four groups of countries that are most similar in terms of changes to their tourism sectors that occurred as a result of the comparison of the situation in 2019 and 2020. The first cluster comprises four countries: France, Greece, Italy, and Romania. The countries in this cluster were characterized by the highest average stringency index. On the other hand, the group recorded the lowest rate of changes in arrivals by air transport. The value of the indicator in this cluster means that the number of arrivals of passengers by air transport decreased by $69.67 \%$. The group was also characterized by the lowest average change of room occupancy in hotels and similar accommodation establishments. The average fall in this group was $19.94 \%$. However, the countries recorded quite a considerable decrease in the change in foreign visitors' overnight stays at tourist accommodation facilities, which was $76.04 \%$ on average (Table 4 ). 


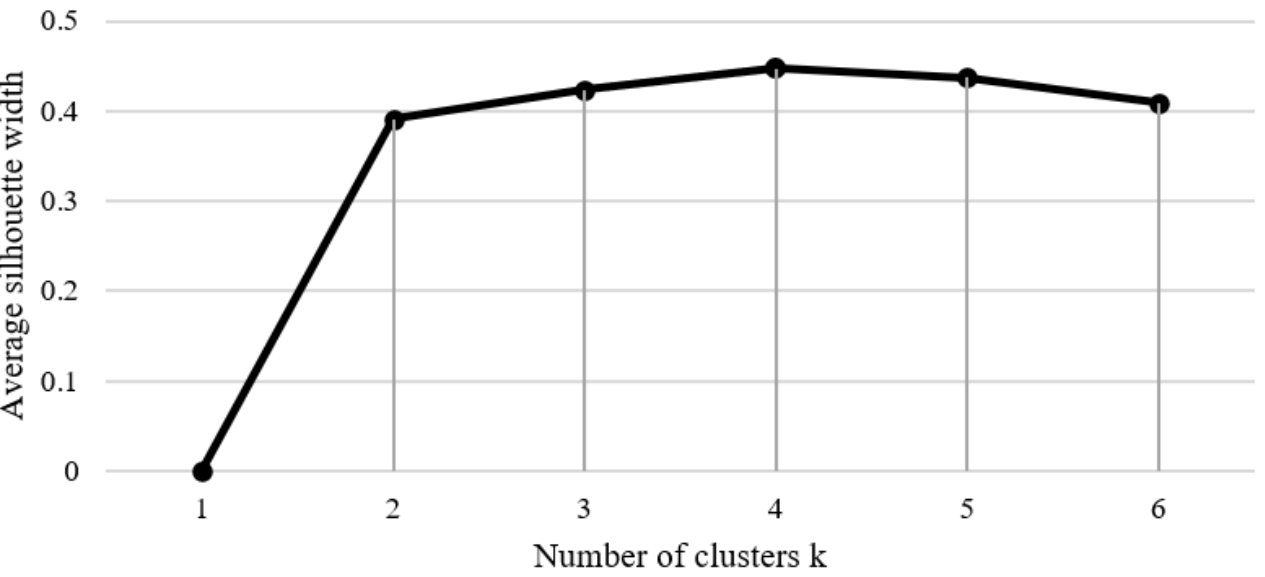

Figure 4. Optimal number of clusters. Source: authors' own preparation.
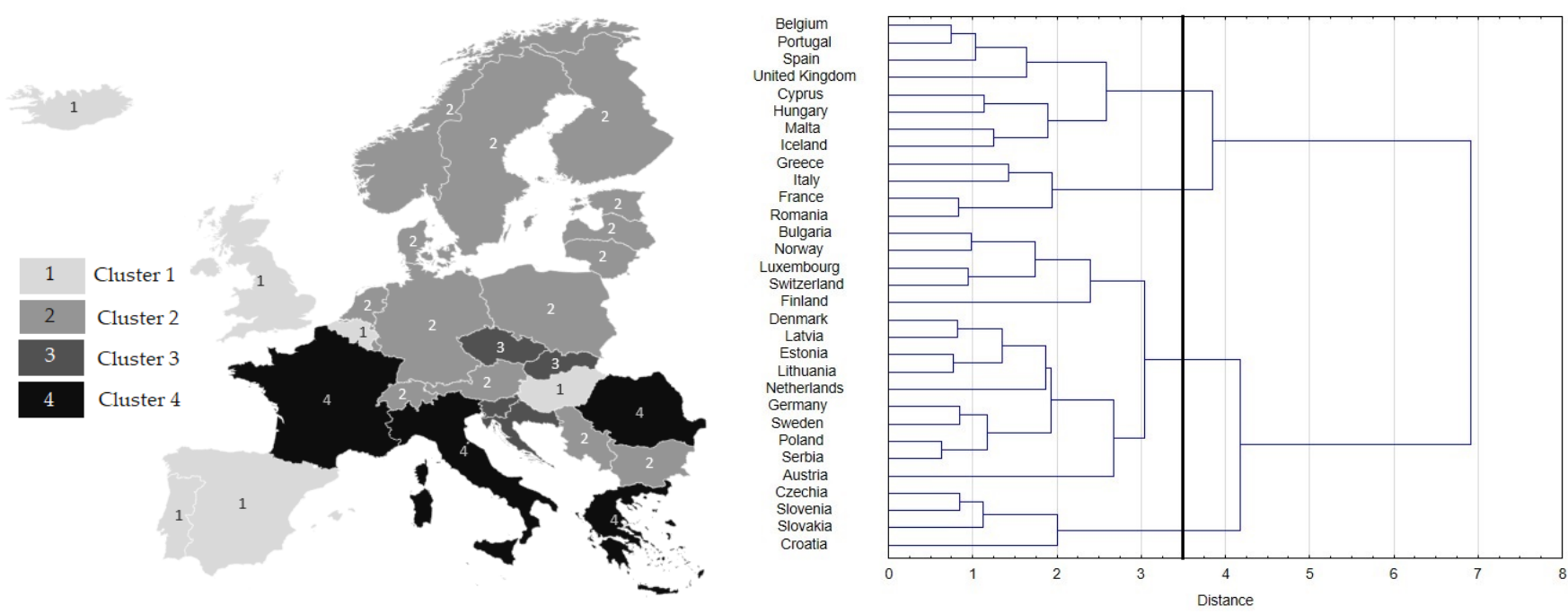

Figure 5. The map and the dendrogram of hierarchical clustering using Ward's method for European countries. Source: authors' own preparation.

The second cluster is composed of 15 countries: Austria, Bulgaria, Denmark, Estonia, Finland, Germany, Latvia, Lithuania, Luxembourg, Netherlands, Norway, Poland, Serbia, Sweden, and Switzerland. The average stringency index and the average change in the number of nights spent and arrivals at tourist accommodation establishments in this cluster were the lowest in comparison with other clusters.

The third cluster is comprised of four countries: Croatia, Czechia, Slovakia, and Slovenia. In comparison with other clusters, the change in air transport arrivals in those countries was the largest and accounted for $81.76 \%$ on average.

The fourth group is composed of eight countries: Belgium, Cyprus, Hungary, Iceland, Malta, Portugal, Spain, and the United Kingdom. In this cluster, the average change in room occupancy in hotels and similar facilities, the change in the number of nights, and the change in arrivals at tourist accommodation establishments were the largest in comparison with other clusters. In addition, these countries were characterized by a relatively significant drop in the number of arrivals by air transport, but a relatively low average stringency index. 
Table 4. Clusters' descriptive characteristics.

\begin{tabular}{|c|c|c|c|c|c|c|c|}
\hline \multicolumn{2}{|c|}{ Cluster } & Statistics & $X_{1}$ & $X_{2}$ & $X_{3}$ & $X_{4}$ & $X_{5}$ \\
\hline \multirow{16}{*}{ Ward's method } & $\mathrm{C} 1$ & \multirow{4}{*}{ Mean } & -69.67 & -19.94 & -76.04 & -56.79 & 59.09 \\
\hline & $\mathrm{C} 2$ & & -71.49 & -23.08 & -62.73 & -44.10 & 47.60 \\
\hline & $\mathrm{C} 3$ & & -81.76 & -23.74 & -66.06 & -52.86 & 48.56 \\
\hline & $\mathrm{C} 4$ & & -74.85 & -37.27 & -76.25 & -63.72 & 53.61 \\
\hline & $\mathrm{C} 1$ & \multirow{4}{*}{ Minimum } & -67.45 & -16.20 & -70.21 & -49.90 & 68.41 \\
\hline & $\mathrm{C} 2$ & & -62.26 & -2.49 & -44.04 & -35.42 & 57.95 \\
\hline & $\mathrm{C} 3$ & & -79.98 & -15.21 & -57.95 & -47.78 & 52.91 \\
\hline & $\mathrm{C} 4$ & & -69.80 & -28.69 & -69.13 & -58.15 & 60.18 \\
\hline & $\mathrm{C} 1$ & \multirow{4}{*}{ Maximum } & -72.52 & -24.42 & -81.09 & -65.97 & 52.84 \\
\hline & $\mathrm{C} 2$ & & -75.06 & -39.57 & -73.03 & -50.50 & 38.49 \\
\hline & $\mathrm{C} 3$ & & -83.37 & -31.78 & -72.82 & -64.21 & 45.82 \\
\hline & $\mathrm{C} 4$ & & -79.63 & -49.35 & -84.10 & -71.72 & 41.68 \\
\hline & $\mathrm{C} 1$ & \multirow{4}{*}{ Standard deviation } & 1.82 & 3.55 & 4.19 & 6.35 & 5.72 \\
\hline & $\mathrm{C} 2$ & & 3.39 & 7.68 & 7.64 & 4.39 & 5.27 \\
\hline & $\mathrm{C} 3$ & & 1.30 & 5.95 & 5.95 & 6.64 & 2.65 \\
\hline & $\mathrm{C} 4$ & & 3.42 & 7.07 & 4.08 & 4.16 & 5.86 \\
\hline
\end{tabular}

Source: authors' own preparation.

In addition, the dispersion of variables across clusters was analyzed. Standard deviation states how wide the values of variables are diffused around the mean. The leastdispersed variable was the change of arrivals by air passenger transport $\left(\mathrm{X}_{1}\right)$. This proves that there are minor differences between countries within one cluster. On the other hand, the change in the occupancy rate at tourist accommodation establishments was characterized by the greatest dispersion $\left(\mathrm{X}_{2}\right)$. However, it should be noted that the standard deviation did not exceed $8 \%$, so we were dealing with a good fit of countries within individual clusters.

The resulting four clusters are of great importance for the future of tourism in the crisis and post-crisis times of the COVID-19 pandemic. The clusters present the results obtained when selecting specific variables for individual European countries that are visited by tourists to a greater or lesser degree. Such statements are important because they make it possible to ascertain which countries will be visited more often after the COVID-19 pandemic. Additionally, it is possible to determine which countries are better able to deal with the economic crisis caused by the COVID-19 pandemic. Such statistical summaries should be prepared not only for European countries, but also for countries on other continents.

\section{Discussion and Recommendations}

The COVID-19 pandemic, and the activities undertaken by the governments of particular countries resulting in a partial or complete lockdown of selected branches of the economy in order to contain the pandemic, had a negative impact on the economic situation of most national economies. The reduction in production and consumption in the countries that were particularly hit by the pandemic went so far as to cause an economic slowdown. The results of the research indicate a significant decline in global production capacity in 2020, taking into account the marked reduction in fixed investment [47].

The radical restrictions on social and economic activeness and barriers to tourist traffic undoubtedly contributed to that effect. One of the most evident economic consequences of the epidemic is a clear decrease in the speed of economic growth, in both European countries and the rest of the world. This decrease particularly concerns those countries where tourism is one of the most important industries that determine the economic potential of their national economies [48]. Forecasts indicate that the virus limited global economic growth to around $-3.2 \% y / y$ in 2020, and the opposite trend is expected in 2021. However, last year's economic slowdown was not as negative as initially forecast, among other things due to fiscal and monetary policy [49].

This article presents an evaluation of the influence of the COVID-19 pandemic on 31 European countries. The diagnostic variables also take into account the stringency index, 
which affects the economic potential of particular countries. The impact of the COVID-19 pandemic on the countries' economic growth and the economic situation in the tourist industry has been already noted. Considerable travel restrictions, both for private and business purposes, as well as restrictions on and barriers to tourist traffic contributed to the dire situation in the tourism industry, resulting in companies losing financial liquidity and sometimes even leading to bankruptcy [50]. In addition, the negative consequences had a knock-on effect and hit sectors connected with tourism. Therefore, the worsening of the business situation was noted to a greater extent in countries where the tourism industry has a large share in the generation of GDP. The countries with the highest financial losses due to the travel restrictions in the 2020 pandemic year include Italy and Spain [51].

On the other hand, if we take a long-term perspective, the pandemic may change the picture of the global economy, resulting in a partial withdrawal from common globalization processes. There may still be increased interest in smaller tourist accommodation facilities, a higher demand for domestic tourist services or tourist services in countries located close together, and a probable rise in prices of global tourist traffic resulting from the considerable economic losses caused by the travel restrictions and limitations currently in force [52].

Before the breakout of the COVID-19 pandemic, global economic growth remained moderate while also very diverse. The economic recovery in developed countries was accompanied by a fall in the development dynamics in many emerging economies, including that of Poland. The USA enjoyed a good economic situation, with rising employment figures and a reduction in unemployment, which was conducive to improving the situation in the labor market and seeing increases in social wellbeing. A recovery of economic activeness in the Eurozone also took place, despite serious concerns about the stability of the process. The state of uncertainty resulted from the fact that the European economy was suffering from a financial and migration crisis. Bureaucracy, corruption, and speculation were spreading. Therefore, it appeared necessary to reform the European Union and adopt a strategy for responsible development.

On the other hand, the temporary lockdowns of national economies in particular countries, which were a response to the sudden acceleration of the pandemic and the resulting problems occurring in healthcare systems and across entire societies, caused a considerable worsening of the economic situation. According to the International Monetary Fund, the estimated global decrease in growth in 2020 reached $-3.5 \%$, which was $0.9 \%$ worse than was foreseen. Although the latest acceptance of vaccination has given hope for containing the pandemic this year, successive waves and new variants of the virus raise concerns about the prospects [53].

As mentioned above, the crisis caused by the COVID-19 pandemic affects countries' economic growth and development. On the one hand, what must be emphasized are the economic aspects of the epidemic, i.e., the decrease in households' purchasing power, the fall in demand for private and business travel services, problems with maintaining financial liquidity, numerous redundancies, etc. On the other hand, one cannot forget the serious social consequences of the COVID-19 pandemic, which at present hamper not only growth, but also the economic development of countries.

Despite this situation, it is also necessary to consider certain positive consequences of the situation. Crisis-related events have encouraged people to look for new development paths, to undertake entrepreneurial activities, and to introduce innovation [54]. These events also concern entrepreneurs in the tourism sector who, although severely hit by the pandemic, have made decisions taking into account changes occurring in the outside surroundings and have striven to enhance the competitiveness of their own companies as well as that of their entire regions [55].

Development trends and the adoption of smart destinations and tourist services, along with artificial intelligence, robotics, and other digital achievements, are now being accelerated in order to fight against the consequences for tourism of COVID-19 [56]. Innovative solutions, such as mobility monitoring applications, non-contact provision of services, digital health passports and identity checks, social distance technologies, and 
crowd control may undoubtedly have an impact on the reopening of tourism [57]. The COVID-19 pandemic is a wake-up call and a chance for the tourism industry to adopt the mindfulness movement, trusting in its capacity to reflect on the current problems and to pave a new way towards more compassionate and meaningful tourism for both hosts and guests [58].

\section{Conclusions}

The COVID-19 pandemic has seriously affected the tourism sector around the world. This article clusters European countries according to the influence that the COVID-19 pandemic has had on the tourism sector in a given country. In order to do that, a multicriteria analysis tool—cluster analysis-was used. Five indicators were applied to achieve the aim, looking at the change in arrivals by air passenger transport; the change in the occupancy rates of bedrooms in tourist accommodation establishments; the change in the number of nights spent by foreign visitors at tourist accommodation establishments; the change in arrivals at tourist accommodation establishments; and a stringency index. The analysis was carried out for the period 2019-2020 and used Ward's method.

Based on the research conducted, it can be observed that (1) the most significant changes in the tourism sector were recorded in April, May, and June 2020 (the beginning of the pandemic in Europe and a time of severe restrictions), as well as in December 2020; (2) although all European countries incurred losses in the tourism sector in 2020, there are considerable differences among those countries examined; (3) four distinct groups of European countries have been identified in terms of changes in the tourism sector caused by the COVID-19 pandemic; (4) the cluster analysis findings show that the largest decreases in the tourism-related variables under investigation were recorded in Spain, Cyprus, Hungary, Malta, Iceland, Belgium, Portugal and the United Kingdom.

The results of the study can be a valuable source of information for entrepreneurs and managers, as well as for government representatives, because they show the similarity of individual European countries in terms of the impact of the COVID-19 pandemic on the tourism sector. This information can help identify areas for improvement, as well as facilitate important decisions to increase the competitiveness of the sector in individual countries. Identifying countries in a similar situation will enable governments to indicate pathways for the further development of the tourism sector, taking into account the crisis arising from the COVID-19 pandemic. It is particularly important to ensure the sustainable development of EU countries in this area.

Although the aim of the article has been achieved, it should be noticed that the research is not free of limitations. The cluster analysis using Ward's method was carried out on only five indicators, which were selected on substantive grounds but based on available data (convenient selection). Despite certain limitations, our research constitutes an interesting starting point for future research. The methodology applied in this article can be reconstructed using other indicators and evaluating the phenomenon under investigation in a few years' time. Another suggestion is to apply the same indicators, but to use other multi-criteria methods (the method of analytical hierarchization or the TOPSIS method, for example) in order to compare the results received or to develop a country-rating system.

The topic presented in this article is an important one and concerns current issues related to changes in tourism caused by the COVID-19 pandemic. The original calculations of four clusters were among the key goals of the article. A new methodological element in this article can be considered as a way of systematizing the concepts of changes in tourism caused by the COVID-19 pandemic. The topic is very broad and the research is not fully exhausted. There are dynamic changes in tourism, and therefore it is worth continuing to study the problems in the future and to carry out similar calculations, e.g., by selecting other diagnostic variables. It is also necessary to conduct qualitative research with the owners of accommodation facilities (e.g., hotels, motels, guesthouses, and agritourism farms) by asking them questions about the losses they have suffered. 


\begin{abstract}
Author Contributions: Conceptualization, M.R. (Michał Roman), M.R. (Monika Roman), E.G., P.P. and K.R.; data curation, M.R. (Monika Roman); formal analysis, M.R. (Michał Roman), M.R. (Monika Roman), E.G., P.P. and K.R.; funding acquisition, M.R. (Michał Roman), M.R. (Monika Roman), E.G., P.P. and K.R.; investigation, M.R. (Michał Roman), M.R. (Monika Roman) and K.R.; methodology, M.R. (Monika Roman); project administration, M.R. (Michał Roman), M.R. (Monika Roman) and E.G.; resources, M.R. (Michał Roman), M.R. (Monika Roman), E.G., P.P. and K.R.; software, M.R. (Monika Roman); supervision, M.R. (Michał Roman) and M.R. (Monika Roman); validation, M.R. (Michał Roman) and M.R. (Monika Roman); visualization, M.R. (Michał Roman) M.R. (Monika Roman), E.G., P.P. and K.R.; writing—original draft, M.R. (Michał Roman), M.R. (Monika Roman), E.G., P.P. and K.R.; writing—review \& editing, M.R. (Michał Roman), M.R. (Monika Roman), E.G., P.P. and K.R. All authors have read and agreed to the published version of the manuscript.
\end{abstract}

Funding: This research received no external funding.

Institutional Review Board Statement: Not applicable.

Informed Consent Statement: Not applicable.

Data Availability Statement: Not applicable.

Conflicts of Interest: The authors declare no conflict of interest.

\title{
References
}

1. Andersson, T. The tourist in the experience economy. Scand. J. Hosp. Tour. 2007, 7, 46-58. [CrossRef]

2. World Tourism Organization (UNWTO). World Tourism Barometer 2017; WTO: Geneva, Switzerland, 2017 ; Volume 15.

3. WTTC. Economic Impact Reports. Available online: https://wttc.org/Research/Economic-Impact (accessed on 11 January 2022).

4. Santos, A.; Cincera, M. Tourism demand, low cost carriers and European institutions: The case of Brussels. J. Transp. Geogr. 2018, 73, 163-171. [CrossRef]

5. Juul, M. Tourism and the European Union. Recent Trends and Policy Developments; European Parliamentary Research Service: Brussels, Belgium, 2015; Volume 1.

6. Weston, R.; Guia, J.; Mihalič, T.; Prats, L.; Blasco, D.; Ferrer-Roca, N.; Lawler, M.; Jarratt, D. Research for TRAN Committee-European Tourism: Recent Developments and Future Challenges; Policy Department for Structural and Cohesion Policies, European Parliament: Brussels, Belgium, 2019; Volume 11.

7. WTTC. Recovery Scenarios 2020 and Economic Impact from COVID-19. Available online: https://wttc.org/Portals/0/ Documents / Reports / 2020/Travel\%20Tourism\%20Recovery\%20Scenarios\%202020\%20and\%20Economic\%20Impact \%20from\% 20COVID-19.pdf?ver=2021-02-25-183040-927 (accessed on 14 June 2021).

8. UNWTO. COVID-19 Related Travel Restrictions a Global Review for Tourism. Ninth Report as of 8 March 2021. Available online: https:/ / webunwto.s3.eu-west-1.amazonaws.com/s3fs-public/2021-03/210309-Travel-Restrictions.pdf (accessed on 15 June 2021).

9. Škare, M.; Soriano, D.R.; Porada-Rochoń, M. Impact of COVID-19 on the travel and tourism industry. Technol. Forecast. Soc. Chang. 2021, 163, 120469. [CrossRef]

10. Plzáková, L.; Smeral, E. Impact of the COVID-19 crisis on European tourism. Tour. Econ. 2021. [CrossRef]

11. UNWTO. International Tourist Numbers Could Fall 60-80\% in 2020, UNWTO Reports. 18 June 2020. Available online: https: / / www.unwto.org/news/ covid-19-international-tourist-numbers-could-fall-60-80-in-2020 (accessed on 12 June 2021).

12. Iacus, S.M.; Natale, F.; Santamaria, C.; Spyratos, S.; Vespe, M. Estimating and projecting air passenger traffic during the COVID-19 coronavirus outbreak and its socio-economic impact. Saf. Sci. 2020, 129, 104791. [CrossRef]

13. UNCTAD. Global Economy Could Lose over \$4 Trillion due to COVID-19 Impact on Tourism. Available online: https://unctad. $\mathrm{org} /$ news/global-economy-could-lose-over-4-trillion-due-covid-19-impact-tourism (accessed on 11 January 2022).

14. Frochot, I.; Batat, W. Marketing and Designing the Tourist Experience; Goodfellows: Oxford, UK, 2013; Volume 8.

15. Gössling, S.; Scott, D.; Hall, M. Pandemics, tourism and global change: A rapid assessment of COVID-19. J. Sustain. Tour. 2020, 29, 1-20. [CrossRef]

16. World Bank. Air Transport, Passengers Carried. Retrieved 4 April 2020. Available online: https://data.worldbank.org/indicator/ is.air.psgr (accessed on 11 January 2022).

17. World Bank. International Tourism, Number of Arrivals. Retrieved 4 April 2020. Available online: https:/ /data.worldbank.org/ indicator/ST.INT.ARVL (accessed on 11 January 2022).

18. Roman, M.; Bhatta, K.; Roman, M.; Gautam, P. Socio-Economic Factors Influencing Travel Decision-Making of Poles and Nepalis during the COVID-19 Pandemic. Sustainability 2021, 13, 11468. [CrossRef]

19. Tourism for Development. 20 Reasons Sustainable Tourism Counts for Development; Tourism for Development Knowledge Series; World Bank Group: Washington, DC, USA, 2017; Available online: https://openknowledge.worldbank.org/handle/10986/28388 (accessed on 11 January 2022). 
20. ICAO. Effects of Novel Coronavirus (COVID-19) on Civil Aviation: Economic Impact Analysis. Available online: https:/ / www.icao.int/sustainability/Documents/COVID-19/ICAO\%20COVID\%202021\%2012\%2008\%20Economic\%20 Impact\%20TH\%20Toru.pdf (accessed on 10 January 2022).

21. Polyzos, S.; Samitas, A.; Spyridou, A.E. Tourism demand and the COVID-19 pandemic: An LSTM approach. Tour. Recreat. Res. 2020, 46, 175-187. [CrossRef]

22. Uğur, N.G.; Akbıyık, A. Impacts of COVID-19 on global tourism industry: A cross-regional comparison. Tour. Manag. Perspect. 2020, 36, 100744. [CrossRef]

23. Fotiadis, A.; Polyzos, S.; Huan, T.C. The good, the bad and the ugly on COVID-19 tourism recovery. Ann. Tour. Res. 2021, 87, 103117. [CrossRef]

24. Kaushal, V.; Srivastava, S. Hospitality and Tourism Industry amid COVID-19 Pandemic: Perspectives on Challenges and Learnings from India. Int. J. Hosp. Manag. 2020, 92, 102707. [CrossRef] [PubMed]

25. Tran, B.L.; Chen, C.C.; Tseng, W.C.; Liao, S.Y. Tourism under the Early Phase of COVID-19 in Four APEC Economies: An Estimation with Special Focus on SARS Experiences. Int. J. Environ. Res. Public Health 2020, 17, 7543. [CrossRef] [PubMed]

26. Higgins-Desbiolles, F. Socialising tourism for social and ecological justice after COVID-19. Tour. Geogr. 2020, 22, 610-623. [CrossRef]

27. Qiu, R.T.R.; Park, J.; Li, S.; Song, H. Social costs of tourism during the COVID-19 pandemic. Ann. Tour. Res. 2020, 84, 1-14. [CrossRef]

28. Zheng, Y.; Goh, E.; Wen, J. The effects of misleading media reports about COVID-19 on Chinese tourists' mental health: A perspective article. Anatolia-Int. J. Tour. Hosp. Res. 2020, 31, 337-340. [CrossRef]

29. Brouder, P. Reset redux: Possible evolutionary pathways towards the transformation of tourism in a COVID-19 world. Tour. Geogr.-Int. J. Tour. Space Place Environ. 2020, 22, 484-490. [CrossRef]

30. Farzanagen, M.R.; Gholipour, H.F.; Feizi, M.; Nunkoo, R.; Andargoli, A.E. International Tourism and Outbreak of Coronavirus (COVID-19): A Cross-Country Analysis. J. Travel Res. 2020, 60, 687-692. [CrossRef]

31. Correa-Martinez, C.L.; Kampmeier, S.; Kumpers, P.; Schwierzeck, V.; Hennies, M.; Hafezi, W.; Kuhn, J.; Pavenstadt, H.; Ludwig, S.; Mellmann, A. A Pandemic in Times of Global Tourism: Superspreading and Exportation of COVID-19 Cases from a Ski Area in Austria. J. Clin. Microbiol. 2020, 58, 1-3. [CrossRef]

32. Yu, M.; Li, Z.; Yu, Z.; He, J.; Zhou, J. Communication related health crisis on social media: A case of COVID-19 outbreak. J. Curr. Issues Tour. 2020, 24, 2699-2705. [CrossRef]

33. Niewiadomski, P. COVID-19: From temporary de-globalisation to a re-discovery of tourism? Tour. Geogr. 2020, 22, 651-656. [CrossRef]

34. Carr, A. COVID-19, indigenous peoples and tourism: A view from New Zealand. Tour. Geogr. 2020, 22, 491-502. [CrossRef]

35. Chang, C.L.; McAleer, M.; Ramos, V. A Charter for Sustainable Tourism after COVID-19. Sustainability 2020, 12, 3671. [CrossRef]

36. Prideaux, B.; Thompson, M.; Pabel, A. Lessons from COVID-19 can prepare global tourism for the economic transformation needed to combat climate change. Tour. Geogr. 2020, 22, 667-678. [CrossRef]

37. Wen, J.; Kozak, M.; Yang, S.; Liu, F. COVID-19: Potential effects on Chinese citizens' lifestyle and travel. Tour. Rev. 2020, 76, 74-87. [CrossRef]

38. Felbermayr, G.; Hinz, J.; Chowdhry, S. Après-ski: The spread of coronavirus from Ischgl through Germany. Ger. Econ. Rev. 2021, 22, 415-446. [CrossRef]

39. Nhamo, G.; Dube, K.; Chikodzi, D. Conclusions and Policy Recommendations: Building Back Better Global Tourism Systems Post-COVID-19. In Counting the Cost of COVID-19 on the Global Tourism Industry; Springer: Cham, Switzerland, 2020. [CrossRef]

40. Vasenska, I.; Koyundzhiyska-Davidkova, B. Tourism Customer Attitudes During the COVID-19 Crisis. In Culture and Tourism in a Smart, Globalized, and Sustainable World; Springer Proceedings in Business and Economics; Katsoni, V., van Zyl, C., Eds.; Springer: Cham, Switzerland, 2021. [CrossRef]

41. Our World in Data. COVID-19: Stringency Index. Available online: https://ourworldindata.org/covid-stringency-index (accessed on 19 September 2021).

42. EUROSTAT. Available online: https:/ / ec.europa.eu/eurostat/web/main/data/database (accessed on 19 September 2021).

43. Hans-Friedrich, K.; Lawrence, J.H. Hierarchical Cluster Analysis; Wiley StatsRef: Statistics Reference Online; John Wiley \& Sons, Ltd.: Hoboken, NJ, USA, 2015. [CrossRef]

44. Rencher, A.C. Cluster Analysis. In Methods of Multivariate Analysis; Rencher, A.C., Ed.; John Wiley \& Sons, Inc.: Hoboken, NJ, USA, 2002; pp. 451-503.

45. Murtagh, F.; Legendre, P. Ward's Hierarchical Agglomerative Clustering Method: Which Algorithms Implement Ward's Criterion? J. Classif. 2004, 31, 274-295. [CrossRef]

46. Roman, M.; Górecka, A.; Roman, M. Wykorzystanie Transportu Pasażerskiego w Rozwoju Turystyki; WULS Press: Warsaw, Poland, 2019; Available online: https:/ / www.ieif.sggw.pl/wp-content/uploads/2019/09/Roman-Go\%CC\%81recka-Roman-Transportw-turystyce.pdf (accessed on 15 June 2021).

47. Coutiño, A.; Zandi, M. Global loss of production capacity caused by the COVID-19 pandemic. J. Policy Modeling 2021, 43, 493-502 [CrossRef]

48. Ritchie, B.W.; Jiang, Y. A review of research on tourism risk, crisis, and disaster management. Ann. Tour. Res. 2019, 79, 102812. [CrossRef] 
49. Congressional Research Service, Global Economic Effects of COVID-19. Available online: https://sgp.fas.org/crs/row / R46270 .pdf (accessed on 11 January 2022).

50. Wieprow, J.; Gawlik, A. The Use of Discriminant Analysis to Assess the Risk of Bankruptcy of Enterprises in Crisis Conditions Using the Example of the Tourism Sector in Poland. Risks 2021, 9, 78. [CrossRef]

51. Roman, M.; Roman, M.; Niedziółka, A. Spatial Diversity of Tourism in the Countries of the European Union. Sustainability 2020, 12, 2713. [CrossRef]

52. Nunkoo, R.; Seetanah, B.; Jaffur, Z.R.K.; Moraghen, P.G.W.; Sannassee, V. Tourism and economic growth: A Meta-regression analysis. J. Travel Res. 2019, 59, 404-423. [CrossRef]

53. International Monetary Fund. World Economic Outlook Update, January 2021. Available online: https://www.imf.org/en/ Publications/WEO/Issues/2021/01/26/2021-world-economic-outlook-update (accessed on 11 January 2022).

54. Kraus, S.; Clauss, T.; Breier, M.; Gast, J.; Zardini, A.; Tiberius, V. The economics of COVID-19: Initial empirical evidence on how family firms in five European countries cope with the corona crisis. Int. J. Entrep. Behav. Res. 2020, 26, 1067-1092. [CrossRef]

55. Wachyuni, S.S.; Kusumaningrum, D.A. The Effect of COVID-19 Pandemic: How are the Future Tourist Behavior? J. Educ. Soc. Behav. Sci. 2020, 33, 67-76. [CrossRef]

56. Shin, H.; Kang, J. Reducing perceived health risk to attract hotel customers in the COVID-19 pandemic era: Focused on technology innovation for social distancing and cleanliness. Int. J. Hosp. Manag. 2020, 91, 102664. [CrossRef] [PubMed]

57. Sigala, M. Tourism and COVID-19: Impacts and implications for advancing and resetting industry and research. J. Bus. Res. 2020, 117, 312-321. [CrossRef]

58. Stankov, U.; Filimonau, V.; Vujičić, M.D. A mindful shift: An opportunity for mindfulness-driven tourism in a post-pandemic world. Tour. Geogr. 2020, 22, 703-712. [CrossRef] 